University of New Hampshire

University of New Hampshire Scholars' Repository

\title{
$9-1989$
}

\section{The Chernobyl Reference Horizon (?) in the Greenland Ice Sheet}

Jack E. Dibb

University of New Hampshire, jack.dibb@unh.edu

Follow this and additional works at: https://scholars.unh.edu/earthsci_facpub

Part of the Atmospheric Sciences Commons

\section{Recommended Citation}

J. Dibb, "The Chernobyl reference horizon (?) in the Greenland ice sheet," Geophysical Research Letters, vol. 16, no. 9, pp. 987-990, Sep. 1989.

This Article is brought to you for free and open access by the Earth Sciences at University of New Hampshire Scholars' Repository. It has been accepted for inclusion in Earth Sciences Scholarship by an authorized administrator of University of New Hampshire Scholars' Repository. For more information, please contact Scholarly.Communication@unh.edu. 


\title{
THE CHERNOBYL REFERENCE HORIZON (?) IN THE GREENLAND ICE SHEET
}

\author{
Jack Dibb
}

Glacier Research Group, University of New Hampshire

\begin{abstract}
Published reports of the presence of radioactive debris from the Chernobyl reactor accident in snow on the Greenland ice sheet raised the strong prospect that such debris might constitute a valuable time stratigraphic marker all over the ice sheet. Large volume snow samples to test this possibility were collected from 7 snowpits as part of a wide ranging regional snow chemistry survey conducted during 1987 and 1988. Snow "labeled" with Chernobyl derived radioactivity was detected in all of the pits. However, the total amount of radioactive debris found at the different locations varied over a 20 fold range. The variability in total fallout showed no clear large scale spatial pattern that could be related to the presumed progress of the radioactive plume over Greenland, suggesting that small scale differences in precipitation pattern and reworking of the snow by wind were predominantly responsible for the patchy preservation of the Chernobyl "layer" on the Greenland ice sheet.
\end{abstract}

Reports of a distinctive layer of snow with high radioactivity due to the Chernobyl accident in northern (Pourchet et al., 1986) and southern Greenland (Davidson et al., 1987), and our own observation of a similar layer in a snowpit dug at Summit in the 1987 season, suggested that the accident had provided a valuable time stratigraphic marker for researchers over all of the Greenland ice sheet. However, new results from a series of six snowpits sampled during the 1988 season indicate that the amount of Chernobyl fallout in Greenland snow varies markedly over very small spatial scales and may be difficult to detect in some places.

Large volume (ca. $1 \mathrm{~kg}$ ) samples at continuous $6 \mathrm{~cm}$ depth intervals were cut from the sampling wall of the snowpits. An established clean sampling protocol (Mayewski et al., 1986) was followed throughout the sampling process. The snow blocks were double bagged in polyethylene, returned to New Hampshire frozen and stored at $-20^{\circ} \mathrm{C}$ until they were prepared for analysis. The radiocesium in the samples was concentrated by the ion-exchange filter technique of Delmas and Pourchet (1975) and was determined by high resolution gamma spectrometry. The counting facility consists of a Canberra $\mathrm{Ge}$ well detector connected to a computer based multi-channel analyzer. ${ }^{137} \mathrm{Cs}$ was determined by the area of the $662 \mathrm{kev}$ photopeak, both the 605 and $796 \mathrm{kev}$ photopeaks were used for ${ }^{134} \mathrm{Cs}$. Counting times ranged from 12 to 24 hours depending on the activity of the sample.

The depth to the Chernobyl layer in the 1987 and 1988 pits provides local accumulation rates for the period since the accident (Table 1). In southern Greenland accumulation of $1.0-1.3 \mathrm{~m}$ of snow/year generally agrees with regional estimates for longer periods based on stratigraphic techniques (Benson, 1962). The $3.4 \mathrm{~m}$ depth of the Chernobyl layer in pit 8 is somewhat anomalous, but this pit showed extensive melt features which may have caused migration and smearing of the contaminated layer. At Summit and near Camp Century (Pits 1 and 2) recent accumulation rates determined from Chernobyl fallout (ca. 0.8 and $1.0-1.1 \mathrm{~m}$ of snow/year,

Copyright 1989 by the American Geophysical Union.

Paper number 89GL01622.

0094-8276/89/89GL-01622\$03.00 respectively) are also similar to previous long-term estimates (Benson, 1962).

The concentration of radiocesium in the individual layers varied over a 30 fold range (if Pit 8 is not considered) (Tabie 1). While some of this variability certainly reflects real patchiness in the distribution, much of it may be an artifact due to the coarse depth resolution of sampling relative to the short period of fallout. Conversion of the concentration values to areal inventories (considering only the "Chernobyl labeled" layers) eliminates the effects of accumulation rate differences and reduces sampling artifacts, but still shows a factor of 20 variability in the distribution of Chernobyl fallout in Greenland snow (Table 1 and Figure 1). Although there appears to be a tendency for higher levels in northern Greenland, there seems to be no strong relation between the spatial distribution of Chernobyl fallout and altitude, topography and location on the ice sheet with respect to the presumed path of the plume (Figure 1). It may be that there was minimal deposition (or retention) of Chernobyl fallout near the broad saddle between Dye 3 and Summit due to a funneling of wind, but the extreme variability over very small spatial scales suggests that small scale local topography played a dominant role in determining the pattern of Chernobyl fallout preserved in the snow.

The fallout from Chernobyl observed in Europe immediately following the accident was noteable for its extreme spatial heterogeneity (Ambach et al., 1988; Clark and Smith, 1988; Fry et al., 1986; Haeberli et al., 1988; Hohenemser et al., 1986). In one $40,000 \mathrm{~km}^{2}$ region of Germany 30 fold differences in total deposition were observed (Hohenemser et al., 1986). Much of the variability in Europe was attributed to patchiness in both the radioactive plume so near to its source and in precipitation intercepting the plume (ApSimon et al., 1988). The greater transport distance to Greenland should have tended to homogenize the plume, minimizing this source of variability. It is hard to imagine a combination of wet and dry deposition processes creating the 3 - 4 fold difference in the amount of Chernobyl fallout in Pit 7 and the site $23 \mathrm{~km} \mathrm{SW}$ of Dye 3 (roughly $25 \mathrm{~km}$ apart), let alone the 3 fold difference between the pits sampled by Davidson and coworkers in 1986 and 1987 at essentially the same location (separation ca. $1000 \mathrm{~m}$ ). However, the ready redistribution of newly fallen snow by wind, and the tendency of this process to fill in depressions in the surface at the expense of local highs (Gow, 1965; Palais, 1984), would seem capable of creating such variability on the scale of meters.

Fallout from the Chernobyl accident does now constitute a very useful time horizon in firn on the Greenland ice sheet. However, the relatively quick passage of the radioactive plume created just a very thin layer of labeled snow which appears to have been redistributed by post-depositional processes. As a result, the Greenland ice sheet has preserved a very patchy, perhaps even discontinuous, layer of Chernobyl debris. The uneven preservation of the Chernobyl "horizon" in Greenland should serve as yet another warning of the extreme care that must be exercised when extrapolating findings from samples of such limited spatial extent as snowpits or ice cores to larger regions. As a minimum precaution, deep coring efforts must include a companion study of spatial variability based on high resolution sampling of a network of snowpits or shallow cores. 
TABLE 1. Chernobyl Fallout in Greenland

\begin{tabular}{|c|c|c|c|c|c|c|}
\hline \multirow[b]{2}{*}{ Location } & \multirow[b]{2}{*}{ Date } & \multirow{2}{*}{$\begin{array}{l}\text { Depth of } \\
\text { Labeled Layers }\end{array}$} & \multicolumn{2}{|c|}{ Concentration ${ }^{a}$} & \multicolumn{2}{|c|}{$\begin{array}{l}\text { Inventorya } \\
\mathrm{pCi} / \mathrm{m}^{2}\end{array}$} \\
\hline & & & $134 \mathrm{Cs}$ & ${ }^{137} \mathrm{Cs}$ & ${ }^{134} \mathrm{Cs}$ & ${ }^{137} \mathrm{Cs}$ \\
\hline Station Nord $\mathrm{b}$ & $5 / 8 / 86$ & Fresh & 3.6 & 6.7 & $18-54$ & $34-102$ \\
\hline $81^{\circ} 36^{\prime} \mathrm{N}$ & $5 / 12 / 86$ & Snow & 3.6 & 7.7 & $18-54$ & $\underline{38-115}$ \\
\hline $16^{\circ} 40^{\prime} \mathrm{W}$ & & & & Total & $36-108$ & $72-217$ \\
\hline $\begin{array}{l}23 \mathrm{~km} \mathrm{SW} \text { of } \\
\text { Dye } 3\end{array}$ & July $1986^{c}$ & $10-20$ & $2.0 \pm .8$ & $6.2 \pm 1.4$ & 72 & 220 \\
\hline ca. $65^{\circ} \mathrm{N}$ & July $1987^{d}$ & $95-100$ & $0.69 \pm .14$ & $2.26 \pm .20$ & 14 & 45 \\
\hline ca. $44^{\circ} \mathrm{W}$ & & $100-105$ & $0.27 \pm .05$ & $\stackrel{1.54 \pm .15}{\text { Total }}$ & $2 \frac{6}{20}$ & $\frac{37}{82}$ \\
\hline Summit & $5 / 8 / 87$ & $80-90$ & $5.10 \pm .30$ & $16.56 \pm .54$ & 175 & 570 \\
\hline Pit $1{ }^{\mathrm{e}}$ & $5 / 2 / 88$ & $192-198$ & $0.17 \pm .15$ & $0.43 \pm .05$ & $4-5$ & $10-12$ \\
\hline $77^{\circ} 11^{\prime} \mathrm{N}$ & & $198-204$ & $0.93 \pm .08$ & $3.44 \pm .14$ & $22-25$ & $83-93$ \\
\hline $60^{\circ} 43^{\prime} \mathrm{W}$ & & $\begin{array}{l}204-210 \\
210-216\end{array}$ & $\begin{array}{l}1.14 \pm .15 \\
0.43 \pm .15\end{array}$ & $\begin{array}{r}2.67 \pm .12 \\
0.62 \pm .09 \\
\text { Total }\end{array}$ & $\begin{array}{l}27-31 \\
10-12 \\
63-73\end{array}$ & $\begin{array}{r}64-72 \\
15-17 \\
172-194\end{array}$ \\
\hline Pit $2^{e}$ & $5 / 8 / 88$ & $216-222$ & $1.24 \pm .15$ & $3.85 \pm .19$ & $30-34$ & $92-104$ \\
\hline $77^{\circ} 12^{\prime} \mathrm{N}$ & & $222-228$ & $2.16 \pm .25$ & $6.06 \pm .40$ & $\underline{52-58}$ & $145-163$ \\
\hline $59^{\circ} 12^{\prime} \mathrm{W}$ & & & & Total & $\overline{82-92}$ & $237-267$ \\
\hline $\begin{array}{l}\text { Pit } 5^{\mathrm{e}} \\
66^{\circ} 57^{\prime} \mathrm{N} \\
44^{\circ} 29^{\prime} \mathrm{W}\end{array}$ & $5 / 19 / 88$ & $257-263$ & $0.54 \pm .15$ & $0.96 \pm .07$ & $13-15$ & $23-26$ \\
\hline Pit $6^{\mathrm{e}}$ & $5 / 21 / 88$ & $228-234$ & $0.36 \pm .04$ & $0.55 \pm .05$ & $8-10$ & $13-15$ \\
\hline $67^{\circ} 12^{\prime} \mathrm{N}$ & & $234-240$ & $0.46 \pm .20$ & $1.03 \pm .06$ & $11-13$ & $25-28$ \\
\hline $43^{\circ} 48^{\prime} \mathrm{W}$ & & & & Total & $19-23$ & $38-43$ \\
\hline Pit $7^{e}$ & $5 / 28 / 88$ & $222-228$ & $0.41 \pm .15$ & $0.60 \pm .05$ & $10-11$ & $14-16$ \\
\hline $64^{\circ} 46^{\prime} \mathrm{N}$ & & $228-234$ & $0.72 \pm .30$ & $1.35 \pm .12$ & $\underline{17-20}$ & $\underline{32-36}$ \\
\hline $44^{\circ} 07^{\prime} \mathrm{W}$ & & & & Total & $27-31$ & $46-52$ \\
\hline Pit 8 e & $5 / 31 / 88$ & $33-339$ & $0.37 \pm .16$ & $0.22 \pm .04$ & $9-10$ & $5-6$ \\
\hline $65^{\circ} 38^{\prime} \mathrm{N}$ & & $339-345$ & $0.03 \pm .05$ & $0.09 \pm .03$ & $\leq 1$ & $\underline{2}$ \\
\hline $43^{\circ} 40^{\prime} \mathrm{W}$ & & & & Total & $9-10$ & $7-\overline{8}$ \\
\hline
\end{tabular}

a Corrected to $5 / 1 / 86$.

b From Pourchet et al., 1986. For estimation of inventory a snowfall depth of $5 \mathrm{~cm}$ and a density range of $0.1-0.3 \mathrm{~g} / \mathrm{cm}^{3}$ were assumed.

c From Davidson et al., 1987.

d From Davidson et al., 1989.

e Estimation of inventories for $1988 \mathrm{UNH}$ snowpits assumed a density range of $0.40-0.45 \mathrm{~g} / \mathrm{cm}^{3}$. 


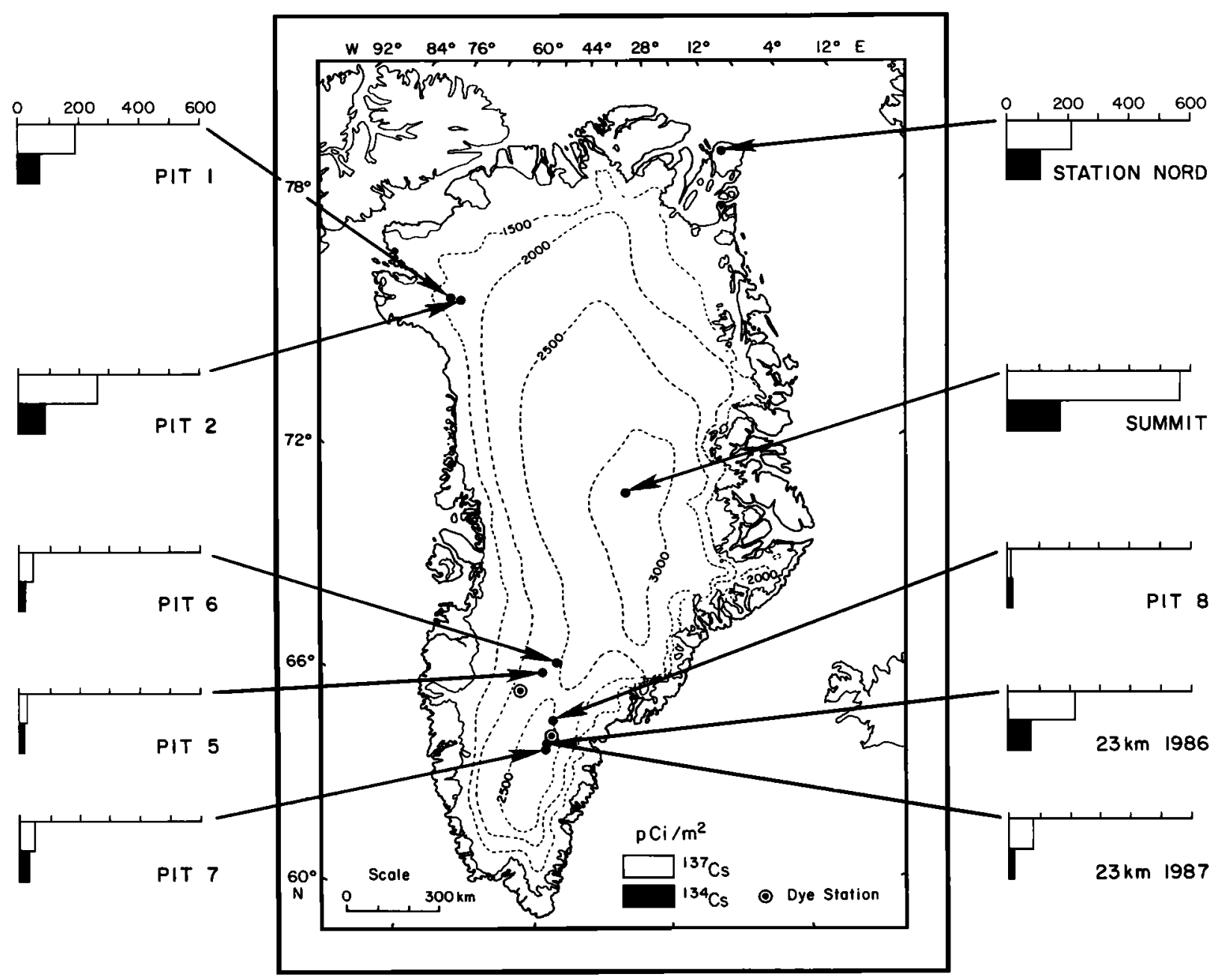

Fig. 1. Inventory of radiocesium from the Chernobyl accident in snow on the Greenland ice sheet. The high end of the ranges listed in Table 1 are plotted.

Acknowledgements. I would like to thank the GRG field team of P. Mayewski (leader), M. Twickler, C. Wake, M. Hussey and S. Drummey for collecting the samples and K. Swanson of PICO for providing them with logistical support. Thanks are also due C. Davidson for providing the values from his 1987 snowpit The field program was funded by NSF grant \# DPP 8619158 to P. Mayewski. I gratefully acknowledge the support of the W. M. Keck Foundation, which allowed GRG to acquire and maintain the radionuclide counting facility.

\section{REFERENCES}

Ambach, W., W. Rehwald, M. Blumthaler, H. Eisner and P. Brunner, 1988, Chernobyl fall-out on glaciers in the Austrian Alps; J. Gaciol., 34 (255-256).

ApSimon, H. M., K. L. Simms and C. G. Collier, 1988, The use of weather radar in assessing deposition of radioactivity from Chernobyl across England and Wales, Atmos. Environ., 22 (1895-1900).

Benson, C. S., 1962, Stratigraphic studies in the snow and firn of the Greenland ice sheet; U.S. Army Snow Ice and Permafrost Research Establishment, res. rept. 70.
Clark, M. J., and F. B. Smith, 1988, Wet and dry deposition of Chernobyl releases; Nature, 332 (245-249).

Davidson, C. I., J. R. Harrington, M. J. Stephenson, M. C. Monaghan, J. Pudykiewicz and W. R. Schnell, 1987, Radioactive cesium from the Chernobyl accident in the Greenland ice sheet; Science, 237 (633-634).

Davidson, C. I., J. R. Harrington, M. J. Stephenson, M. J. Small, F. P. Boscoe and R. E. Gandley, 1989, Seasonal variations in sulfate, nitrate, and chloride in the Greenland ice sheet: Relation to atmospheric concentrations; Atmospheric Environment, in press.

Delmas, R., and M. Pourchet, 1975, Utilization de filtres echangeurs d'ion pour l'etude de l'activitie globale d'un carrotage glaciologique; in Isotopes and Impurities in Snow and Ice Symposium, IAHS - AISH pub. \#118, (159-163).

Fry, F. A., R. H. Clarke and M. C. O'Riordan, 1986, Early estimates of UK radiation doses from the Chernobyl reactor; Nature, 321 (193-195).

Gow, A. J., 1965, Snow studies in Antarctica; CRREL res. rept. 177.

Haeberli, W., H. Gaggler, U. Baltensperger, D. Jost and U. Schotterer, 1988, The signal from the Chernobyl accident in high-altitude firn areas of the Swiss Alps; Ann. Glaciol., $10(48-51)$. 
Hohenemser, C. M. Deicher, H. Hofsass, G. Lindner, E. Recknagel and J. I. Budnick, 1986, Agricultural impact of Chernobyl: a warning; Nature, 321 (817).

Mayewski, P. A., W. B. Lyons, M. J. Spencer, M. Twickler, W. Dansgaard, B. Koci, C. I. Davidson and R. E. Honrath, 1986, Sulfate and nitrate concentrations from a south Greenland ice core; Science, 232 (975-977).

Palais, J. M., 1984, Snow stratigraphic investigations at Dome C, east Antarctica; Institute of Polar Studies, Ohio State University, rept. no. 78.
Pourchet, M., J. F. Pinglot and J. C. Gascard, 1986, The northerly extent of Chernobyl contamination; Nature, 323 (676).

Jack Dibb, Glacier Research Group, University of New Hampshire, Institute for the Study of Earth, Oceans, and Space, Durham, New Hampshire 03824.

(Received: March 24, 1989; accepted: August 3, 1989) 